\title{
TWO THEORIES OF SCIENTIFIC KNOWLEDGE
}

BRUCE AUNE

University of Massachusetts

My aim in discussing two theories of scientific knowledge is to make a case for one being wrong and one being right. There would be little point in doing this if the wrong theory were not commonly accepted as the right one. I shall attempt to show, therefore, why the theory of scientific knowledge commonly taken to be correct is really mistaken, and why a theory often dismissed as mistaken is really correct. I adopt this approach as a means of focusing sharp attention on a dispute that, in my view, is of fundamental importance to the theory of knowledge.

According to most philosophy textbooks, the two rival theories of scientific knowledge are associated with the names "rationalism" and "empiricism". These are not the alternatives I shall discuss, however. I shall assume that any acceptable or, today, even tempting theory of scientific knowledge must conform to the vague demands of empiricism. I say "vague demands of empiricism", because the essential spirit of empiricism-its critical, undogmatic charactermay be possessed by theories sharply opposed to the views actually held by traditional empiricists. For lack of better names, I shall provisionally dub the theories I wish to discuss the "foundations" theory and the "no foundations" theory.

The foundations theory views scientific knowledge as an organized structure resting on a foundation of basic certainty. The foundation is deemed necessary, because the substantive claims of a science are generally reached by a complicated 
process of inference. Since the certainty we can attain by inference always depends on the certainty of our premises, we must have some intrinsically certain premises if we are to have any genuine scientific knowledge at all. The fact that a conclusion $C$ is inferable from a premise $P$ is not enough to prove that $C$ is true; to know that $C$ is true by reference to $P$ we must also know that $P$ is true. $P$ might, of course, be inferable from some other premise $Q$, but, again, if we are to use $Q$ in verifying $P$, we must know that $Q$ is true. To avoid a hopeless regress we must therefore admit that some premises can be know to be true without inferencethat their certainty is somehow intrinsic to them. Such premises can be said to constitute the necessary foundation for our scientific knowledge.

Connected with the idea that scientific knowledge requires a foundation is the idea that scientific meaning requires a foundation. Just as ordinary scientific statements are inferable from more basic statements-and, ultimately, from statements whose truth can be directly known-so, it is urged, the descriptive or scientific meaning of an expression must be definable (capable of elucidation) in terms of more basic expressions-and, ultimately, in terms of the most basic descriptive expressions, which may be called "primitive". The foundations theory of scientific knowledge thus involves the double claim that a scientifically acceptable view of the world rest on primitive truths and primitive units of meaning.

To commit yourself to this twofold claim of the foundations theory is not to commit yourself to any specific account of how primitive truths are to be identified and how primitive units of meaning gain their peculiar significance. On the contrary, both empiricists and rationalists have accepted the foundations theory and yet have differed radically about the status of primitive truths and primitive units of meaning. The rationalist Descartes was in fact a pioneer in articulating the foundations ideal; and although empiricists such as Hume were eager to repudiate the Cartesian philosophy, they 
nevertheless accepted the structural ideal according to which it was built.

The root quarrel between rationalists and empiricists is actually best seen against the background of this common ideal of knowledge. As a means of locating primitive scientific truths, Descartes had urged a method of systematic doubt. "If you find something you cannot doubt and whose indubitability is not due to an obvious inference from some equally indubitable premise, then you have found a primitive scientific truth". Traditional empiricists also accepted this method of doubt; in fact, they even accepted Descarte's first first principle, namely, that thinking exists. (This indubitable premise was needed for Descarte's basic inference, "I think; therefore I am". To build up the edifice of his knowledge, however, Descartes had to rely on other first principles with an unmistakably scholastic air-for example, the principle that there must be as much formal reality in a cause as is contained, formaly and objectively, in its effect. Since empiricists regarded these other Cartesian first principles as easily dubitable-Hume finding it positively easy to doubt even such nonscholastic premises as "Every event has a cause"- they were able to put their finger on what they took to be the key weaknesses of Cartesianism and of rationalism generally.

For the most part, the rationalists held that the basic truths of scientific knowledge fall into two classes-those about which we have innate knowledge (such as the law of causation), and those which are directly evident in our experience (for example, that we feel pain). In addition to this twofold classification of primitive truths, most rationaists accepted a twofold classification of primitive units of meaning, or, as it used to be expressed, primitive ideas. Some of these ideas, such as that of cause or substance, were regarded as innate, and others, such as headache, were thought to be immediately generated by experience. It is a familiar story, applauded in our century, that empiricists 
restricted scientifically primitive truths to those directly evident in experience, and restricted scientific ideas to those that arise "from experience". Later empiricists who spoke of primitive linguistic expressions instead of primitive ideas restricted such expressions to those "ostensively definable" by reference to experience. Any descriptive expressions not ostensively definable, or not definable in relation to such expressions, were then held to be scientifically objectionable or, as it was often put, "empty and meaningless". This brought the notorious verificationist theory of meaning squarely into the philosophical arena. ${ }^{1}$

It is well known that Anglo-Saxon philosophy has been predominantly in the tradition of Hume's empiricism. It is also well known that the basic assumptions of this tradition have been a persistent source of trouble. The notion of experience is, of course, ambiguous, but the basic assumption that scientific truth and meaning must be firmly rooted in experience has led empiricists from one difficulty to another.

The older empiricists interpreted "experience" as meaning "subjective o r private experience". As a result of this, their basic epistemic commitments made it difficult for them to avoid solipsism, or utter skepticism about the existence and nature of other persons and a common world. The story is a familiar one. Although we can directly experience certain things as related in particular ways and thus, given the soundness of standard methods of statistical induction, have probable knowledge of general propositions concerning our own immediate experience, we can have no experience of any relation that might hold between our experience and something that we do not experience. Whether this something else is an external world or another mind, we cannot establish through our immediate experience any generalizations relating this something else to what we do experience. On the contrary, since legitimate scientific terms must either

1 The most influential statement of this theory is contained in A. J. Ayer's Language, Truth, and Logic (London, 1936). 
be ostensively defined by reference to our immediate experience or else explicable in terms of those that are ostensively learned, it is difficult to see how any sense can be made of a world, or a domain of objects generally, that exists independently of immediate experience.

To avoid this kind of solipsism or extreme skepticism empiricists spent years trying to develop a plausible form of phenomenalism-a view implying that other persons and an external world may be interpreted as constructs out of one's immediate experience. ${ }^{2}$ They will be constructs in the sense that everything we can legitimately say about them must be translatable in some way into a more basic idiom that speaks only of our immediate experience. Of course, numerous variations were made on this phenomenalist theme, the constant temptation being to admit certain "postulates" into the system which would make it seem more realistic and less procrustean. ${ }^{3}$ Since these postulates were incapable of validation by rigid empiricist principles - and were indeed the sort of thing that rationalists would claim to be innate principles or synthetic a priori truths-the basic demands of the foundations theory were tacitly violated. ${ }^{4}$

For reasons difficult to summarize--but partly because of the evidently hopeless consequences of the egocentric predicament generated by a subjective foundation for knowledge-philosophers in our time have sought a new foundation of knowledge in what is publicly observable. ${ }^{5}$ Em. piricists accepting this new foundation of knowledge were easily able to avoid the worst problems of the older em. piricism. Specifically, they had no trouble avoiding solipsism

2 See A. J. Ayer, Foundations of Empirical Knowledge (London, 1940) and H. H. Price, Hume's Theory of the External World (Oxford, 1940).

3 Bertrand Russell introduced such postulates in his Human Knowledge: Its Scope and Limits (London, 1948).

4 See Russell, pp. 506-527.

5 See Rudolf Carnap, "Testability and Meaning, I-IV," Phil. of Science, 1936-37; reprinted in H. Feigl and M. Brodbeck, eds., Readings in the Philo. sophy of Science (New York, 1953), pp. 47-92. Also see Anthony Quinton, "The Problem of Perception," Mind, 1955. 
or skepticism about the existence and nature of a publicly observable world. Nevertheless, the older problems stayed with them in spirit, for analogues of these older problems immediately arose to plague them. These analogues concerned our knowledge of scientific objects - such things as molecules - and the subjective experience of others. Knowledge of such things became highly problematic, because they stand in the very same relation to the new foundation of public observability as the external world and other persons stood to the old foundation of subjective experience. Thus, since the feelings of others, as well as scientific entities such as hydrogen molecules, are not publicly observable, there is no way of observing their relation to what we do observe. To accomodate our presumed knowledge of such entities and to give at least the semblance of plausibility to the new version of empiricism, philosophers began to defend what might be called a phenomenalism of scientific objects and subjective experience. Versions of analytical behaviorism accordingly became popular (roughly, statements about mental states are equivalent to complicated statements about behavior) ${ }^{6}$ and scientific theories were commonly given an instrumentalist interpretation: ${ }^{7}$ they were regarded as mere instruments of prediction or as calculating devices, which strictly lacked objective reference.

The difficulty with subjective experience and scientific entities was not just that their existence could not apparently be inferred from what is observable; it was also that talk about them as actual entities was regarded as suspect if the words denoting these alleged entities could not be defined in relation to words denoting items that are publicly observable. In other words, the twin assumptions of the foundation picture, which concern both scientific meaning and scientific truth, gave the new empiricists just as much trouble with

* See Rudolf Carnap, "Psychology in Physicalist Language," in A. J. Ayer, ed., Logical Positivism (New York, 1959), pp. 165-198, and Gilbert Ryle, The Concept of Mind (London, 1949).

i See Stephen Toulmin, Philosophy of Science (London, 1953). 
mental states and scientific entities as the old empiricists had with other persons and an external world.

In the last decade or so, philosophers sympathetic to the foundations theory have sought to save it by weakening its demands. They have attempted this, roughly, by permitting looser relations between the foundation and what may be built upon it. They would still insist that the foundationnow taken as what is publicly observable-is the ultimate source of meaning and scientific certainty, but they would now allow that, for example, a theory of certain unobservable entities may be rendered acceptable and least "partially interpreted" by an indirect relation to the foundation.

I shall not supply details regarding the suggested means of saving the foundations theory by weakening its basic demands, because my chief purpose in this paper is to argue that the foundations theory should be abandoned rather than amended. I shall now proceed to develop my reasons for this opinion.

For the empiricist, primitive truths of a factual kind are to be ascertained by some kind of observation or perception. Let us assume that "observation" refers to the observation of a public object, and let us begin with the case of the other person. His observations are expressed in observation claims, and we must trust these claims if we are to accept his observations as supplying us with empirical truth. Note, however, that if a man claims to see a needle in a haystack or a bear in the bush, we do not immediately accept his claim as true. The acceptability of a man's spontaneous claim always depends, in fact, on our knowledge of the kind of object observed and on our assumptions concerning his reliability as an observer. Are the objects in point easy to see? Are they liable to be mistaken for other things? Does the man have good eyes? Is he honest, sane, sober, and unlikely to

8 See Rudolf Carnap, "The Methodological Character of Theoretical Con. cepts," in H. Feigl and M. Scriven, eds., Minnesota Studies in the Philosophy of Science, Vol. I (Minneapolis, 1956), pp. 38-76. 
be carried away by a vivid imagination? As the possibility of raising these questions makes clear, it is only relative to general empirical assumptions regarding both the perceiver and the perceived that any observation claim-by a man's own self or by anybody else-is ever considered worthy of our acceptance.

An important point to note in this connection is that not all the relevant assumptions can be directly verified by observation. To appreciate this, it is not necessary to become convinced that at least one of them will concern the socalled regularity of nature. It is entirely sufficient to realize that in accepting any observation claim whatever, we must always presuppose that someone or other-either a given observer or someone looking over his shoulder-is at least for the moment a reliable observer, one whose claims regarding the kind of object involved are likely to be true. This last assumption, that someone or other is a reliable observer, cannot possibly be tested by direct observation because any such test would presuppose what it sets out to prove.

The point here may be stated more generally, so that it clearly applies to any kind of putative basic claim, whether it be introspective or observational in something like the ordinary sense. If, for convenience, we call such a claim an observational one, a little reflection will show that the relevant background assumptions will concern four things: the nature of the observer, the character of the objects observed, the particular means of observation, and the conditions under which the observations occurs. The assumptions relevant to these four subjects will obviously range from the very general (or metaphysical, in Collingwood's sense) ${ }^{9}$ to the highly specific, and not all of them can be directly justified by observation itself.

To appreciate the variety of these background assumptions, we might recall some of the questions that can be asked regarding observation. Consider, first, the questions a meta-

9 See R. G. Collingwood, An Essay on Metaphysics (Oxford, 1940). 
physician is likely to ask. "Exactly what is an observer and how, in general, can his claims be checked for reliability? Is an observer a Cartesian spirit, an Aristotelian unit of form and matter, a Hobbesian system of matter in motion, or an ordinary person in the sense of Strawson? $?^{10}$ And what kind of thing is supposed to be observable by such an agentsense data, three-dimensional color solids, or systems or particles? What, moreover, is observation itself? Is it an infallible mental act of direct awareness, a transfer of sensible form from object to sense organ, or perhaps a complicated psycho-physical process involving the transmission of radiation and the firing of millions of neurons? Finally, what count as standard conditions of observation? Is it enough just to have a cool head, or are certain external conditions involving, say, the availability of a certain degree of illumination sometimes of crucial importance as well?"

Consider, now, some of the more concrete questions that might easily arise in discussing a certain form of observation and the claims of a particular agent. "Am I myself a reliable 'observer, or am I perhaps visually abnormal? What about Jones? Can we really trust him when he speaks of the colors he sees? Can a man see a needle or a match-tick at a distance of ten feet? Is it easy to mistake a mirage for an oasis? Do oars really bend under water? Is it always easy to tell whether one is jealous, angry, in love? Does insanity, intoxication, dim light, loud noises, frightening animals, or the presence of haze or fog, increase the likelihood of perceptual error? If so, to what extent?"

As all these questions indicate, the assumptions relevant to the evaluation of a knowledge claim are bound to be numerous, no matter how we interpret the notion of observation. Philosophers accepting the foundations theory tend to underestimate the importance of such assumptions, but they tacitly make them in articulating their views. No philosopher has ever held, after all, that an arbitrary claim ought to be

10 See P. F. Strawson, Individuals (London, 1960), Ch. 4. 
accepted merely because it is advanced with confidence. The basic claims they insist on are supposed to be certain just because they are a special sort of claim-because they concern a special kind of object, and because they are arrived at in a special way by a certain kind of agent under suitable conditions. Thus, for most traditional empiricists, a basic claim compels a subject's assent because it registers his immediate awareness of an object whose esse is, for him, percipi; and for many recent thinkers, a basic claim compels our assent because it is spontaneously made by a responsible person who has proved himself a reliable observer respecting the kind of thing his claim concerns (it might be a brown pig).

Formulated bluntly, the point of these reflections is this: the acceptability and thus certainty of any observation claim is conditional on the acceptability and thus certainty of a system of background assumptions with reference to which the observation claim is to be interpreted and assessed. Since it is obvious that not all of these assumptions can be directly justified by observations, it follows that the foundations picture of empirical knowledge cannot be correct. It is simply false that observation claims can constitute by themselves an ultimate foundation on which the body of our knowledge rests. It is a further consequence of the foregoing argument that observation claims are never intrinsically acceptable. Their acceptability is always conditional; they are acceptable, if at all, only on the condition that certain other claims are acceptable - claims about perceivers, the nature of perception, and the nature of the observable world. Since in virtue of the history of science there is little plausibility in the idea that these background assumptions concerning perceivers and the nature of what is perceived are not subject to revision in the light of further investigation, it follows that there are no intrinsically acceptable empirical claims at all. It is a trivial corolary of these conclusions that the foundations picture of meaning is also mistaken. Experience has to be given a 
conceptual interpretation, and the terms in which this interpretation is given owe their significance to the theories at our disposal; they do not immediately inherit it from a simple confrontation with raw experience.

To argue, as I have, that the acceptability of any observation claim is conditional on the acceptability of a host of background assumptions concerning observers and observable objects is obviously to prompt the question, "How is the acceptability of these background assumptions to be determined?" The answer for some of the assumptions, the lowlevel ones, is hardly a matter of dispute. Observation and inductive reasoning are entirely adequate to establish such modest assumptions as that, for normal observers, needles are difficult to perceive from a distance of more than a dozen feet - even under excellent conditions of illumination. The answer cannot be this simple, however, for higher-level assumptions concerning the nature of observers, observation, and observable objects. The acceptability of many of these assumptions is presupposed by all observation claims and could not, therefore, possibly be established merely by observation and ordinary statistical inference. As I see it, these latter assumptions can be justified only by the success we have in using them. To give any other answer - to say, for in. stance, that they are intuitively-grasped synthetic a priori truths - is plainly to abandon the essential spirit of empiricism, the spirit that must be preserved even if the foundations picture fails.

The opinion just expressed was stated very roughly because some important qualifications have to be made. For one thing, any basic assumption about the world sufficiently plausible to be accepted by sane men can always be protected in such a way that it becomes immune to refutation. This may be done by introducing new assumptions that accomodate any initially recalcitrant facts to the assumptions previously held. If, for example, a man assumes that all sons really hate their fathers, he can accomodate the plain fact that some 
sons show striking affection for their fathers by assuming that such behavior is merely the expression of a deep-seated hostility that a son is unconsciously bending over backward to hide. Clearly, in order to provide a reasonable justification for our basic assumptions, we must avoid this kind of obscurantism. We must be prepared to retain as much simplicity as possible in our theories, and not complicate them merely to protect assumptions that are dear to our hearts. To see the absolute necessity of this is to appreciate the germ of truth (which is all there is) implicit in the verificationist theory of meaning. When we isolate our basic assumptions from any possibility of refutation, however indirect, we implicitly drain them of any assertive content.

To make this admission is not to imply, however, that every legitimate empirical claim must in principle be subject to possible refutation by observation. (This implication was disallowed by my argument that certain claims are presup. posed by every observation whatever). One theory can rather refute another theory, just as the acceptance of a certain theory can undermine the basis for certain kinds of observation statement. Thus, to take some well-worn examples, the phlogiston theory was ruled out by the devolpment of the theory of oxidation; and the observations of Aristotelians respecting the colors of material things were ruled out on the basis of a theory of matter implying that material bodies cannot possibly possess such properties as Aristotelian color.

The general method of reasoning by which many empirical claims, both observational and theoretical, are defended and refuted is extremely complicated and still subject to dispute, at least on matters of detail. Karl Popper calls it "the method of conjectures and refutations", ${ }^{11}$ and others, taking it to apply mainly to theoretical statements, have dubbed it "the method of hypotheses" or "the hypothetico-deductive method". Perhaps the most general remark one can make about it is that a given claim is shown to be acceptable by

11 See K. R. Popper, Conjectures and Refutations (London, 1962). 
reference to the acceptability of the conclusions it allows one to draw when taken in conjuntion with other claims that are regarded as well established. The acceptability of these conclusions is determined, in turn, by their relations to other assumptions that have stood up to criticism and that we have ample reason to trust. The distinctive feature of the method is of course the critical manner in which it is employed. Dogma must be resisted at every stage, and this holds for observations as well as for the rarefied assumptions of new theories. ${ }^{12}$

According to traditional empiricism, each man generates his picture of the world from the raw character of his immediate experience. According to the alternative $\mathrm{I}$ am defending, by the time a man is able to think at all he is operating on a complex body of empirical assumptions, most of which he has simply inherited from his parents and teachers. In attempting to explain and predict the course of his experience in scientific style, he will inevitably generate new assumptions, which will sometimes turn out to be inconsistent with his old ones. When this inconsistency is appreciated (and it is not always easy to see), he must in some way modify his total picture of the world. He may do this in many ways, and there is no simple recipe by which his problem can be solved.

In general, our scientific reasoning generates a growing, changing picture of ourselves and the world. This picture has altered drastically from the time of the ancient Greeks, when the world was conceived of as a living animal whose behavior is to be explained by final causes - and most of us have to consult theoretical scientists for an account of the fine grain of the current picture. Although there is nothing in the new picture that cannot be changed, certain parts of it are obviously more secure than others. To the extent that this picture is based on accurate critical reasoning, we are en-

12 I have discussed the method in some details in my book, Rationalism, Empiricism, and Pragmatism (New York, 1970). 
titled to be confident of its general structure. Even so, we can admit that the ultimate truth about our world is largely an ideal-something that would finally be attained by an enlightened community of scientists if they worked long and hard enough, had good luck and employed the proper methods. This view of empirical knowledge is essentially the theory of critical pragmatism associated with the name of Charles Saunders Peirce. For this reason, the "no foundations" theory defended here might justly be called by the familiar name of "pragmatism." 
Mi propósito al discutir dos teorías distintas acerca del conocimiento científico es el mostrar por qué, aquélla que suele considerarse como la correcta está en realidad equivocada y por qué una teoría generalmente descartada es realmente la correcta.

La alternativa que discuto en este artículo no es aquélla cuyos términos podrían designarse con los nombres de "empirismo" y "racionalismo". Asumo que cualquier teoría del conocimiento científico para ser aceptable debe adecuarse a las vagas demandas del empirismo. Llamaré a las dos teorías que aquí voy a examinar, la "teoría del fundamento" y la "teoría del no fundamento".

Llamo "teoría del fundamento" a aquélla que considera al conocimiento científico como una estructura organizada que descansa sobre un fundamento último de certeza básica. Se estima que dicho fundamento es necesario porque las observaciones sustanciales de una ciencia se alcanzan generalmente mediante un complicado proceso de inferencia. Tendremos que aceptar que hay algunas premisas intrínsecamente ciertas si queremos evitar caer en un lamentable regressus.

Paralela a la idea de que el conocimiento debe tener un funda. mento último corre la idea de que el significado científico requiere también un fundamento: el significado descriptivo o científico de una expresión debe ser definible en términos de expresiones más básicas que podrían ser llamadas "primitivas".

Comprometerse con esta doble tesis de la "teoría del fundamento" no implica comprometerse con una explicación determinada de cómo puedan identificarse esas verdades primitivas ni cómo se constituyen las unidades primitivas de significado. Tanto los empiristas como los racionalistas han aceptado la "teoría del fundamento" y sin embargo sostienen ideas radicalmente diferentes acerca del status de las verdades primitivas y de las unidades primitivas de significado.

Resulta una historia ya bien conocida que los empiristas restringen las verdades científicas primitivas a aquéllas que son directamente evidentes en la experiencia, y las ideas científicas primitivas a aquélla que surgen "a partir de la experiencia". Ya desde Hume, los supuestos básicos de la tradición empirista fueron fuente permanente de problema. La noción de experiencia es de por sí am. bigua, y el supuesto básico de que la verdad y el significado cien- 
tífico deben estar bien enraizados en la experiencia ha dado lugar a múltiples dificultades.

Los empiristas clásicos interpretaban "experiencia" como "experiencia subjetiva o privada". Sus compromisos básicos epistémicos hacían difícil evitar el solipsismo o el escepticimo radical. Para evitar este escepticismo extremo, los empiristas pasaron años tratando de desarrollar una versión plausible de fenomenalismo, el cual es una teoría que sostiene que el mundo exterior y otras personas pueden interpretarse como construcciones a partir de la experiencia inmediata. Existen muchas variaciones sobre el tema del fenomenalismo; la tentación constante ha sido admitir ciertos "postulados" en el sistema los cuales no podrían ser validados por los rígidos principios empiristas. De esta manera se estaría violando tácitamente la idea central de la "teoría del fundamento".

En la época actual, los filósofos han tratado de encontrar un nuevo fundamento del conocimiento en lo públicamente observable. Sin embargo, este nuevo intento también encuentra dos serios problemas: el dar cuenta del conocimiento de objetos científicos no observables y de las experiencias subjetivas de otras personas. Los filósofos entonces intentan defender lo que podría llamares un fenomenalismo de los objetos científicos y las experiencias subjetivas.

En la última década, los filósofos han tratado de salvar la "teoría del fundamento" debilitando sus demandas; parecen permitir relaciones menos rígidas entre el fundamento y lo que se construye sobre él. No trato aquí de explicar los medios que se utilizan para salvar la "teoría del fundamento" porque lo que quiero argumentar es que dicha teoría debe ser abandonada más bien que reformulada.

Para los empiristas, las verdades fácticas primitivas deben apoyarse en algún tipo de observación o percepción. Asumamos que aquí "observación" se refiere a la observación de objetos públicos, y examinemos el caso de que sea una tercera persona la que reporta la observación de un objeto. Su observación la expresa mediante un enunciado de observación en el cual tenemos que confiar si es que hemos de aceptar que su observación nos suministra una verdad empírica. Nótese, sin embargo, que la aceptabilidad de dicho enunciado depende siempre de nuestro conocimiento de la clase de objeto observado y de nuestras presunciones con respecto a la confiabilidad del observador. Un enunciado de observación hecho por un hombre puede considerarse aceptable sólo relativamente a ciertos supuestos empiricos generales. Dichos supuestos se refieren a cuatro cosas: la naturaleza del observador, el carácter de la cosa observada, los medios peculiares de observación y las 
condiciones bajo las cuales se realiza la observación. Un punto importante con respecto a esto es que no todos estos supuestos pueden ser a su vez verificados directamente mediante una observación. Los filósofos que aceptan la "teoría del fundamento" tienden a menospreciar la importancia de estos supuestos, pero tácitamente los están asumiendo cuando estructuran sus teorías.

El punto central de estas reflexiones es el siguiente: la aceptabilidad, y por ende certeza, de cualquier enunciado de observación está condicionada a la aceptabilidad y certeza de un sistema de supuestos con referencia al cual el enunciado de observación puede ser interpretado y respaldado. Dado que es obvio que no todos estos supuestos pueden ser directamente justificados en la observación, se sigue que la "teoría del fundamento" del conocimiento empírico no puede ser correcta. Una consecuencia de lo anterior, es que un enunciado de observación nunca es intrínsecamente aceptable. Con respecto a la "teoría del fundamento" del significado, el corolario de estas conclusiones es que también está equivocada.

Resulta inevitable a estas alturas preguntarse: ¿Cómo puede determinarse la aceptabilidad de los supuestos básicos? Mi opinión es que tales supuestos sólo pueden ser justificados por el éxito que tengamos cuando los usamos.

Es necesario introducir algunas cualificaciones: No cualquier supuesto respecto al cual cualquier dato pueda acomodarse debe ser admitido. Hay que guardar tanta simplicidad como nos sea posible y apreciar el germen de verdad implícito en una teoría verifica. cionista del significado. Esto no quiere decir que cualquier enunciado de observación deba estar sujeto en principio a la posibilidad de refutación mediante otra observación. El llamado método hipotético-deductivo es un método general de razonamiento mediante el cual muchos enunciados empíricos pueden ser defendidos y refutados. De acuerdo con este método, un enunciado puede demostrarse aceptable por las conclusiones que nos permita derivar cuando se tome en conjunción con otros enunciados que se consideran bien establecidos. El rasgo fundamental de este método es su carácter crítico. Este método puede ser empleado para sustituir algunos supuestos básicos por otros.

Según el empirismo tradicional cada hombre genera su idea del mundo a partir de una materia prima que sería su experiencia inmediata. Según el punto de vista que yo defiendo, cuando llega el momento en que el hombre es capaz de pensar está operando ya en medio de un cuerpo complejo de supuestos empíricos, la mayoría de los cuales le han sido simplemente heredados de sus ancestros. Al tratar de dar explicaciones científicas, el hombre adquiere 
nuevos supuestos que en algunos casos podrán mostrarse inconsistentes con los anteriores; el resultado entonces sería que en base a esto el hombre modifica su concepción del mundo. Esto puede suceder repetidas veces.

En general, nuestro razonamiento científico, genera de continuo nuevas concepciones acerca de nosotros mismos y del mundo. En la medida en que dichas concepciones están basadas en un razonamiento crítico podemos confiar en su estructura general.

La teoría aquí expuesta acerca del conocimiento empírico es esencialmente la teoría del pragmatismo crítico asociado con el nombre de Charles Sounders Pierce. 